\title{
POTENSI SORGUM SEBAGAI PRODUK KEWIRAUSAHAAN DI DESA SAYANG KECAMATAN JATINANGOR KABUPATEN SUMEDANG
}

\author{
Endah Wulandari, Elazmanawati Lembong, dan Fitry Filianty \\ Departemen Teknologi Industri Pangan, Fakultas Teknologi Industri Pertanian, Universitas Padjadjaran \\ E-mail: endah.wulandari@unpad.ac.id
}

\begin{abstract}
ABSTRAK Biji sorgum memiliki kandungan karbohidrat yang tinggi sehingga dapat dimanfaatkan sebagai makanan pokok oleh masyarakat. Kegiatan PPM ini bertujuan memetakan data UKM di desa Sayang yang dapat memanfaatkan sorgum sebagai bahan baku UKM/kewirausahaan. Kegiatan PPM ini mendapat sambutan, tanggapan dan perhatian yang cukup baik dari warga sekitar dan pejabat desa setempat. Setelah melakukan wawancara pemetaan dan kuesioner ke ukm, diketahui bahwa masih banyak warga Desa Sayang yang masih belum mengetahui sorgum dan penggunaannya sebagai bahan pangan alternatif, dan untuk pengembangan budidaya sorgum kurang berpotensi untuk dilakukan di wilayah Desa Sayang karena kurang tersedianya lahan. UKM sudah ada di setiap RW minimal 1 UKM tetapi terdapat beberapa masalah yaitu kurangnya modal, peluang, dan pangsa pasar.
\end{abstract}

Kata kunci: Sorgum; Desa Sayang; UKM

ABSTRACT. Sorghum grain have a high carbohydrate content that can be used as a staple food by the community. The service community activity aims to mapping data from SMEs in Sayang village which can utilize sorghum as a raw material for SMEs / entrepreneurship. The service community activity received a warm welcome, response and attention from both local residents and local village officials. After conducting mapping interviews and questionnaires to SMEs, it was found that there were still many residents of Sayang Village who still did not know sorghum and their use as alternative foodstuffs, and that the development of sorghum cultivation had less potential to be done in the Sayang village area due to lack of available land. SMEs already exist in every community group of at least 1 SMEs but there are several problems, namely lack of capital, opportunities, and market share.

Key words : Sorghum; Sayang Village; SMEs

\section{PENDAHULUAN}

Banyak alternatif sumber karbohidrat di Indonesia, namun beras masih menduduki posisi nomor satu sebagai bahan pangan utama. Mengkonsumsi beras padi sudah menjadi budaya yang tidakdapat dilepaskan dari masyarakat Indonesia. Secara tidak disadari, budaya ini juga menjad ipenyebab pemerintah masih mengimpor beras untuk memenuhi kebutuhan nasional. Bahan pangan sumber karbohidrat pengganti diharapkan menjadi solusi bagi Indonesia untuk dapat mengurangi impor atau bahkan memunculkan peluang yang bernilai ekonomis. Salah satu bahan pangan pengganti sumber karbohidrat yang mulai dikembangkan adalah sorgum (Suarni, 2004).

Biji sorgum putih kultivar lokal bandung dapat diolah menjadi tepung sorgum. Kelebihan dari tepung sorgum adalah memiliki kandungan pati yang cukup tinggi, yaitu sekitar 80,42\% (Suarni, 2004). Biji sorgum memiliki kandungan gizi yang baik, seperti karbohidrat, protein, lemak, mineral, dan vitamin, serta tidak mengandung gluten seperti yang terdapat di dalam gandum, sehingga aman untuk penderita penyakit intoleran terhadap gluten seperti autisme, penyakit seliak, dan lain sebagainya (Rukmana dan Oesman, 2001).

Desa Sayang, Jatinangor merupakan salah satu desa yang padat penduduk dan letaknya strategis. Sosialisasi pengenalan pemanfaatan sorgum menjadi produk pangan skala rumah tangga ini diharapkan dapat membantu masyarakat untuk beradaptasi dengan jenis makananbaru dan menjadi wadah untuk berwirausaha. Oleh karena itu, adanya sosialisasi pemanfaatan sorgum di Desa Sayang,
Jatinangor diharapkan dapat memberikan informasi dan juga merangsang kreatifitas masyarakat di sekitar wilayah Universitas Padjadjaran untuk dapat memanfaatkan sorghum sebagai bahan pangan alternatif yang dapat dimanfaatkan untuk keperluan sehari-hari di kemudian hari.

\section{METODE}

Metode yang digunakan adalah deskriptif dengan menggunakan kuisioner kepada sekitar 50 UKM yang bergerak dibidang perdagangan dan pengolahan jasa di daerah Desa Sayang pada bulan Juli 2018. Data deskriptif meliputi jenis kelamin, usia, Nama UKM, nama pengusaha, umur usaha, kepemilikan usaha, alasan memulai usaha, keuntungan, kesulitan bahan baku, perizinan, kendala usaha

\section{HASIL DAN PEMBAHASAN}

Dilihat dari lama usahanya lebih dominan di jangka waktu 1-5 tahun, Kepemilikan status kebanyakan di usaha milik pribadi, alasan mendirikan usaha dominan menjadi wirausaha dan tidak terikat oleh orang lain, omset yang didapati kebanyakan sekitar 2-3 juta.

Masalah peluang dan pangsa pasar sering dialami oleh UKM di Desa Sayang yang berpengaruh terhadap persaingan antar pedagang kecil lainnya dan jenis usaha lainnya. Strategi pemilik usaha (UKM) dalam mengatasi permasalahnnya umumnya dengan meminjam modal dari perbankan. Sulitnya mendapatkan pelanggan tetap dan 
promosi menjadikan UKM di Desa Sayang sulit untuk berkembang. UKM di Desa Sayang rata-rata di bidang kuliner, yang berarti membutuhkan pelanggan tetap dan promosi. Selain itu, pada musim libur sekolah dan perkuliahan, pendapatan UKM di Desa Sayang menurun karena tidak adanya pembeli dikalangan anak sekolahan dan mahasiswa. Masalah kedua yang paling sering dialami UKM di Desa Sayang adalah modal. Cara mengatasinya dengan meminjam kepada bank untuk modal awal usaha.

Cara UKM untuk mengatasi masalah-masalah yang ada, sebagai berikut:

- Mencari bahan baku ketempat lain

- Memberi THR ketika lebaran (agar mendapat pelanggan tetap)

- Melakukan pinjaman ke bank

- Merasa bersyukur dengan apa yang ada

- Meminta pelanggan datang esok hari (memastikan adanya barang esok hari)

- Meningkatkan kualitas produk

- Mengganti makanan

- Membelibahan yang murah agar dapat dijual lebih murah

- Menyesuaikan ukuran produk dengan harga bahan baku
Tabel 1. Informasi Umum Kondisi UKM di Desa Sayang

\begin{tabular}{|c|c|c|c|}
\hline No & Demografi & Pilihan & Jumlah \\
\hline \multirow[t]{4}{*}{1.} & Lama Usaha & $<1$ tahun & 7 \\
\hline & & 1-5 tahun & 13 \\
\hline & & 6-10 tahun & 4 \\
\hline & & $>10$ tahun & 8 \\
\hline \multirow[t]{5}{*}{2.} & Kepemilikan & Pribadi & 17 \\
\hline & & Keluarga & 8 \\
\hline & & $\mathrm{CV}$ & 5 \\
\hline & & $\mathrm{PT}$ & 1 \\
\hline & & Lainnya & 1 \\
\hline \multirow[t]{5}{*}{3.} & Alasan/motivasi & Wirausaha & 13 \\
\hline & & $\begin{array}{l}\text { Melanjutkan usaha } \\
\text { keluarga }\end{array}$ & 7 \\
\hline & & $\begin{array}{l}\text { Tidak dapat } \\
\text { pekerjaan }\end{array}$ & 4 \\
\hline & & $\begin{array}{l}\mathrm{P} \text { e } \mathrm{nd} \text { a } \mathrm{p} \text { a } \mathrm{t} \text { a } \mathrm{n} \\
\text { tambahan }\end{array}$ & 6 \\
\hline & & Lainnya & 2 \\
\hline \multirow[t]{4}{*}{4.} & Omset & $<1$ juta & 3 \\
\hline & & 2-3 juta & 13 \\
\hline & & 3-5 juta & 6 \\
\hline & & $>5$ juta & 11 \\
\hline
\end{tabular}

Target utama UKM di Desa Sayang adalah warga sekitar dengan persentase $60 \%$ dan mahasiswa dengan

Tabel 2. UKM yang Berpotensi Memanfaatkan Sorgum sebagai Produk Industri Pangan Skala Rumah Tangga

\begin{tabular}{|c|c|c|c|c|}
\hline RW & JENIS USAHA & BIDANG USAHA & GOLONGAN USAHA & $\begin{array}{c}\text { BAHAN YANG DAPAT DIGANTI } \\
\text { SORGUM }\end{array}$ \\
\hline 1 & - & - & - & - \\
\hline 2 & $\begin{array}{l}\text { Pedagang dan } \\
\text { Kuliner }\end{array}$ & $\begin{array}{l}\text { Gorengan } \\
\text { Beras }\end{array}$ & Menengah & $\begin{array}{l}\text { Dapat menjual beras yang berasal dari } \\
\text { sorgum, dan pada pembuatan gorengan } \\
\text { dapat menambahkan sorgum sebagai msg. }\end{array}$ \\
\hline 3 & Pedagang & Batagor dan Baso Tahu & Menengah & $\begin{array}{l}\text { Pada pembuatan baso bahan baku yang } \\
\text { dapat diganti yaitu tepung dan msg yang } \\
\text { berbahan sorgum. }\end{array}$ \\
\hline 4 & $\begin{array}{l}\text { Kuliner dan } \\
\text { Pedagang }\end{array}$ & $\begin{array}{l}\text { Warung Nasi } \\
\text { Toko Bahan-bahan kue }\end{array}$ & Menengah & $\begin{array}{l}\text { Pada warung nasi dapat menggunakan } \\
\text { sorgum sebagai nasi, sedangkan pada toko } \\
\text { bahan-bahan kue dapat menjual tepung } \\
\text { sorgum }\end{array}$ \\
\hline 6 & $\begin{array}{l}\text { Pengolahan, } \\
\text { Pedagang dan } \\
\text { Kuliner }\end{array}$ & $\begin{array}{l}\text { Kerupuk melarat } \\
\text { Bakso } \\
\text { Gorengan } \\
\text { Ice Cream } \\
\text { Warung Nasi } \\
\text { Toko kelontong }\end{array}$ & Menengah & $\begin{array}{l}\text { Pada warung nasi dapat menggunakan sorgum } \\
\text { sebagai nasi. Toko kelontong dapat menjual } \\
\text { beras dari sorgum. Dapat menggunakan } \\
\text { tepung untuk bahan baku bakso. Usaha } \\
\text { kuliner dapat menambahkan sorgum sebagai } \\
\text { penambah cita rasa. }\end{array}$ \\
\hline 7 & Pengolahan & $\begin{array}{l}\text { Pembuatan Tahu } \\
\text { Rumah Makan } \\
\text { Cemilan Usus } \\
\text { Toko Kelontong }\end{array}$ & Menengah & $\begin{array}{l}\text { Pada pembuatan tahu sorgum dapat } \\
\text { dimanfaatkan sebagai bahan campuran } \\
\text { pembuatan tahu. Warung nasi dapat } \\
\text { menggunakan sorgum sebagai nasi. Toko } \\
\text { kelontong dapat menjual beras dari sorgum. } \\
\text { Usaha kuliner dapat menambahkan sorgum } \\
\text { sebagai penambah cita rasa. }\end{array}$ \\
\hline 8 & Kuliner & $\begin{array}{l}\text { Fried Chicken } \\
\text { Nyoklat }\end{array}$ & Menengah & $\begin{array}{l}\text { Memanfaatkan sorgum sebagai pengganti } \\
\text { beras dan penambah cita rasa }\end{array}$ \\
\hline 10 & Kuliner & Rumah Makan & Menengah & $\begin{array}{l}\text { Memanfaatkan sorgum sebagai pengganti } \\
\text { beras dan penambah cita rasa }\end{array}$ \\
\hline
\end{tabular}


persentase $20 \%$. UKM lebih menargetkan warga sekitar dibandingkan dengan mahasiswa karena warga sekitar menetap pada daerah tersebut sedangkan mahasiswa berada di daerah tersebut ketika masa perkuliahan saja. Strategi yang dilakukan UKM untuk bersaing dengan UKM lainnya bermacam-macam seperti menjual barang lebih murah dengan kualitas yang sama, meningkatkan kualitas produk, bahan yang dijual lebih lengkap, meningkatkan pelayanan, membuat produk berbeda dan menarik, serta menjaga kebersihan barang dan lingkungan sekitar

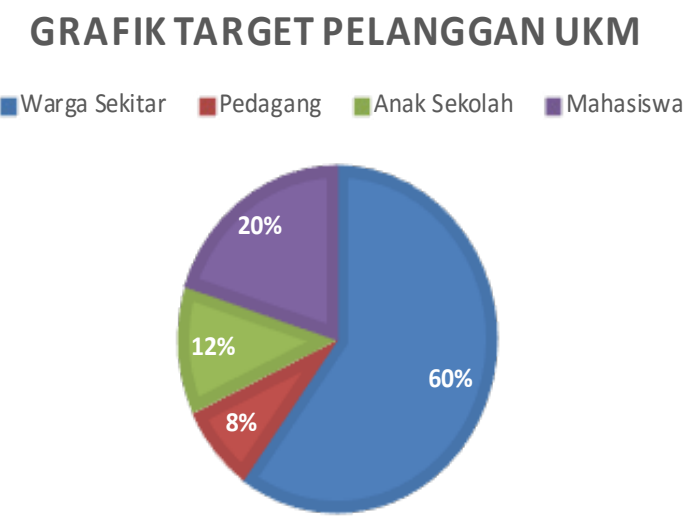

Gambar 1. Grafik Target Utama Pelanggan UKM

Berdasarkan Tabel 2 dapat terlihat, UKM di Desa Sayang yang dapat memanfaatkan sorgum sebagai produk industri pangan rumah tangga ada sekitar 15 UKM yang terdiri dari penjual beras, toko kelontong, pedagang, penjual icecream, dan toko bahan-bahan kue. Pada usaha kuliner dapat memanfaatkan sorgum sebagai bahan penambah citarasa (campuran gula dan MSG) dan tepung. Pada usaha rumah makan sorgum dapat dimanfaatkan sebagai nasipengganti beras dan penambah citarasa. Toko kelontong dan toko bahan-bahan kue dapat menjual tepung sorgum dan beras yang berasal dari sorgum sebagai bahan baku alternatif yang lebih sehat. Selain data tersebut, berdasarkan hasil wawancara dengan Ibu/Bapak RW terdapat UKM lainnya yang dapat memanfaatkan sorgum sebagai bahan baku alternatif yaitu pengusaha kue basah dan cupcakes dengan memanfaatkan sorgum sebagai tepung dan penambah cita rasa.

\section{SIMPULAN}

- UKM Di Desa Sayang terdiri dari pengolahan,jasa, perdagangan dan lainnya yang rata-rata belum banyak memiliki legalitas seperti SIUP, IUMK dan sebagainya dan masalah terbesar UKM Di Desa Sayang adalah modal serta peluang dan pangsa pasar sehingga pengurusan legalitas usaha dan izin edar dapat menjadi solusi permasalahn pangsa pasar.

- UKM yang berpotensi memanfaatkan sorgum sebagai bahan baku alternatif sebanyak 15 UKM yang berasal dari bidang pengolahan, kuliner dan pedagang sehingga sosialisasi dan penggunaan sorgum sebagai bahan baku produk UKM menjadi positif.

\section{UCAPAN TERIMAKASIH}

Ucapan terima kasih penulis sampaikan ke pihak DRPMi Universitas Padjadjaran yang telah membiayai kegiatan Pengabdian kepada Masyarakat ini.

\section{DAFTAR PUSTAKA}

Rukmana, R dan Y.Oesman. 2001. Usaha Tani Sorgum. Kanisius. Jakarta.

Soekarto, S.T. 1985. Penilaian Organoleptik untuk Industri Pangan dan Hasil Pertanian. Bhratara Karya Aksara. Jakarta.

Suarni. 2004. Pemanfaatan Tepung Sorgum Untuk Produk Olahan. Jurnal Litbang Pertanian. Vol 23 (4): 145-151. 